\title{
A new troglobitic schizomid (Hubbardiidae: Paradraculoides) from the Pilbara region, Western Australia
}

\author{
Kym M. Abrams ${ }^{1}$ and Mark S. Harvey $y^{1,2,3,4}$ \\ ${ }^{1}$ Department of Terrestrial Zoology, Western Australian Museum, Locked Bag 49, Welshpool DC, \\ Western Australia 6986, Australia. \\ ${ }^{2}$ Adjunct: School of Animal Biology, University of Western Australia, Crawley, \\ Western Australia 6009, Australia. \\ ${ }^{3}$ Adjunct: School of Natural Sciences, Edith Cowan University, Joondalup, \\ Western Australia 6027, Australia. \\ ${ }^{4}$ Research Associate: Division of Invertebrate Zoology, American Museum of Natural History, \\ 79th Street @ Central Park West, New York, New York 10024-5192, USA. Research Associate: \\ Department of Entomology, California Academy of Sciences, Golden Gate Park, San Francisco, \\ California 94103-3009 USA.
}

\begin{abstract}
A new species of Hubbardiidae, Paradraculoides eremius sp. nov., is described from Bungaroo, Pilbara, Western Australia based on male and female specimens collected from troglofauna traps. Although similar in form to other Paradraculoides known from the Pilbara bioregion, it has a distinctive male flagellum which is distally rounded rather than tapering to a point as in other species. It is known from only a small area of less than $10 \mathrm{~km}^{2}$ in the Hamersley Range.
\end{abstract}

KEYWORDS: taxonomy, morphology, subterranean, short-range endemic

\section{INTRODUCTION}

The Pilbara bioregion is well-known for its distinctive and diverse subterranean fauna. Previous studies have documented a great diversity of invertebrates including insects, crustaceans, worms and arachnids (see Guzik et al. 2011; Humphreys 2006, 2008 and references therein). This fauna is of particular interest due to the large number of species with restricted distributions in habitats that are currently undergoing intensive mineral extraction processes. Due to the abundance of goethite-hematite channel iron deposits or CIDs (formerly known as the Robe pisolite), Bungaroo is one of the sites of interest for resource development and may be mined in future (Ramanaidou et al. 2003) yet very little has been published about the fauna in this area. However, one particularly noteworthy denizen of Bungaroo Creek is the blind cave eel Ophisternon candidum Mees, 1962 (Humphreys et al. 2013) which was originally collected from Cape Range and has 'vulnerable' status under federal (Environment Protection and Biodiversity Conservation Act 1999) and state (Wildlife Conservation Act 1950) threatened species legislation.
One of the best studied components of the Pilbara troglofauna is the arachnid order Schizomida (Harvey 1988, 1992; Harvey and Humphreys 1995; Humphreys 1989). Schizomids are small arachnids that are largely confined to the tropical and subtropical regions of the world and usually inhabit leaf litter or caves. There are 286 species in 53 genera known world-wide (Zawierucha et al. 2013). The Australian fauna comprises 53 species in nine genera, distributed in Western Australia, Northern Territory and Queensland (Harvey 2013). Although many new species have been discovered in the Pilbara bioregion and are awaiting formal description, six species of Draculoides Harvey, 1992 and four species of Paradraculoides Harvey, Berry, Edward and Humphreys, 2008, have been described (Harvey et al. 2008). Eight of these species are currently listed as Schedule 1 Specially Protected Fauna in Western Australia under the Wildlife Conservation Act 1950 due to their restricted distributions in areas potentially threatened by mining activities such as iron ore extraction. Here we describe the first schizomid from Bungaroo in the Hamersley Range (Figure 1), which was collected from subterranean habitats. 


\section{MATERIAL AND METHODS}

The material utilised in the present study is lodged in the Western Australian Museum, Perth (WAM). Terminology and mensuration largely follow Harvey (1992) and Reddell and Cokendolpher (1995). The following abbreviations were used for the setae of the flagellum: dm1, 4 (dorso-median 1, 4), dl1, 3 (dorsolateral 1, 3), vm1, 2, 4, 5 (ventro-median 1, 2, 4, 5), vl1, 2 (ventro-lateral 1, 2).

The specimens were initially stored in $100 \%$ ethanol. Some structures (e.g. chelicera, female genitalia) were dissected from the specimen and examined by preparing temporary slide mounts by immersing the specimen in $75 \%$ lactic acid at room temperature for several days, and mounting them on microscope slides with $10 \mathrm{~mm}$ coverslips supported by small sections of $0.25 \mathrm{~mm}$ or $0.50 \mathrm{~mm}$ diameter nylon fishing line. They were examined with a Leica MZ16 dissecting microscope and a Leica DM2500 compound microscope, and illustrated with a WACOM Intuos Pro digital tablet. Whole body images were taken with a digital camera attached to the MZ16 using Leica Automontage version 3.7.0 software. After study the specimens were returned to $75 \%$ ethanol with the dissected portions placed in $12 \times 3 \mathrm{~mm}$ glass genitalia microvials (BioQuip Products, Inc.).

\section{SYSTEMATICS}

\section{Family Hubbardiidae Cook, 1899}

\section{Subfamily Hubbardifinae Cook, 1899}

\section{Genus Paradraculoides Harvey, Berry, Edward and Humphreys, 2008}

Paradraculoides Harvey, Berry, Edward and Humphreys, 2008: 185.

\section{TYPE SPECIES}

Paradraculoides kryptus Harvey, Berry, Edward and Humphreys, 2008, by original designation.

\section{REMARKS}

The genus Paradraculoides is morphologically very similar to Draculoides, which also occurs in the Pilbara region of Western Australian. Species of both genera share the apomorphic character of a lack of a small mesal spur on the pedipalpal trochanter (Harvey 1992; Harvey et al. 2008). This mesal spur is present in all other Australian schizomids and most other hubbardiid genera (see Reddell and Cokendolpher, 1995 and Harvey et al. 2008 and references therein). Paradraculoides differs from Draculoides and all other hubbardiid genera by the presence of three macrosetae on tergite II.

\section{Paradraculoides eremius sp. nov.}

http://zoobank.org/NomenclaturalActs/262FA90F-857045F7-9EF8-9324DEC2E22A

Figures 2-10

\section{MATERIAL EXAMINED}

Holotype

Australia: Western Australia: Ĵ, Bungaroo, 35.4 $\mathrm{km}$ SE. of Pannawonica, 21 ${ }^{\circ} 56^{\prime} 37 \mathrm{~S}, 116^{\circ} 26^{\prime} 26 \mathrm{E}, 15$ April 2011, troglofauna trap, J. Alexander, S. Werner (WAM T114968). Genbank accession number for CO1: KU291135.

\section{Paratypes}

Australia: Western Australia: 1 , Bungaroo, 34.8 $\mathrm{km}$ SE. of Pannawonica, 21 ${ }^{\circ} 56^{\prime} 07^{\prime}$ 'S, 116 $26^{\circ}$ '54'E, 15 April 2011, troglofauna trap, J. Alexander, and S. Werner (WAM T114972); 1 ते Bungaroo, 35.3 km SE.

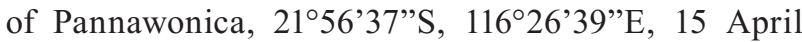
2011, troglofauna trap, J. Alexander, S. Werner (WAM T114969).

\section{Other material examined}

Australia: Western Australia: 1 juvenile, same data as paratype $\widehat{\partial}$ (WAM T114970).

\section{DIAGNOSIS}

The distal end of the male flagellum is distally rounded instead of tapering to a point as in other described Paradraculoides species. Females of this species differ from all other congeneric females by the rectangular-shaped backward folding genital gonopod and the presence of two pairs of sub-terminal microsetae near $\mathrm{d} 13$ and $\mathrm{vl} 2$ on the third segment of the flagellum; other described Paradraculoides species have either one (P. anachoretus, $P$. gnophicola and P. kryptus) or three pairs of sub-terminal microsetae (P. bythius).

\section{DESCRIPTION}

\section{Adults}

Colour: ranging from yellow-brown to dark orangebrown.

Cephalothorax: propeltidium with 9 setae, arranged 2 (in row): 2: 1: 2: 2: 2 anterior margin drawn to a point between chelicerae; eye spots absent. Mesopeltidia widely separated. Metapeltidium divided. Anterior sternum with 14 setae, including two sternapophysial setae; posterior sternum triangular, with 6-7 (ठ), $7($ ( ) setae.

Chelicera: fixed finger with two large teeth plus five smaller teeth between these, basal and distal teeth each with one small, blunt, lateral tooth; brush at base of fixed finger composed of eight $(\hat{\jmath}), 7$ (ㅇ) setae, each densely pilose in distal half; lateral surface with three large, lanceolate, terminally pilose setae; internal face of chelicera with 4 short whip-like setae, no serrations visible; movable finger file composed of 20 (ठ), 18 (ㅇ) long lamellae, blunt guard tooth present subdistally, one 


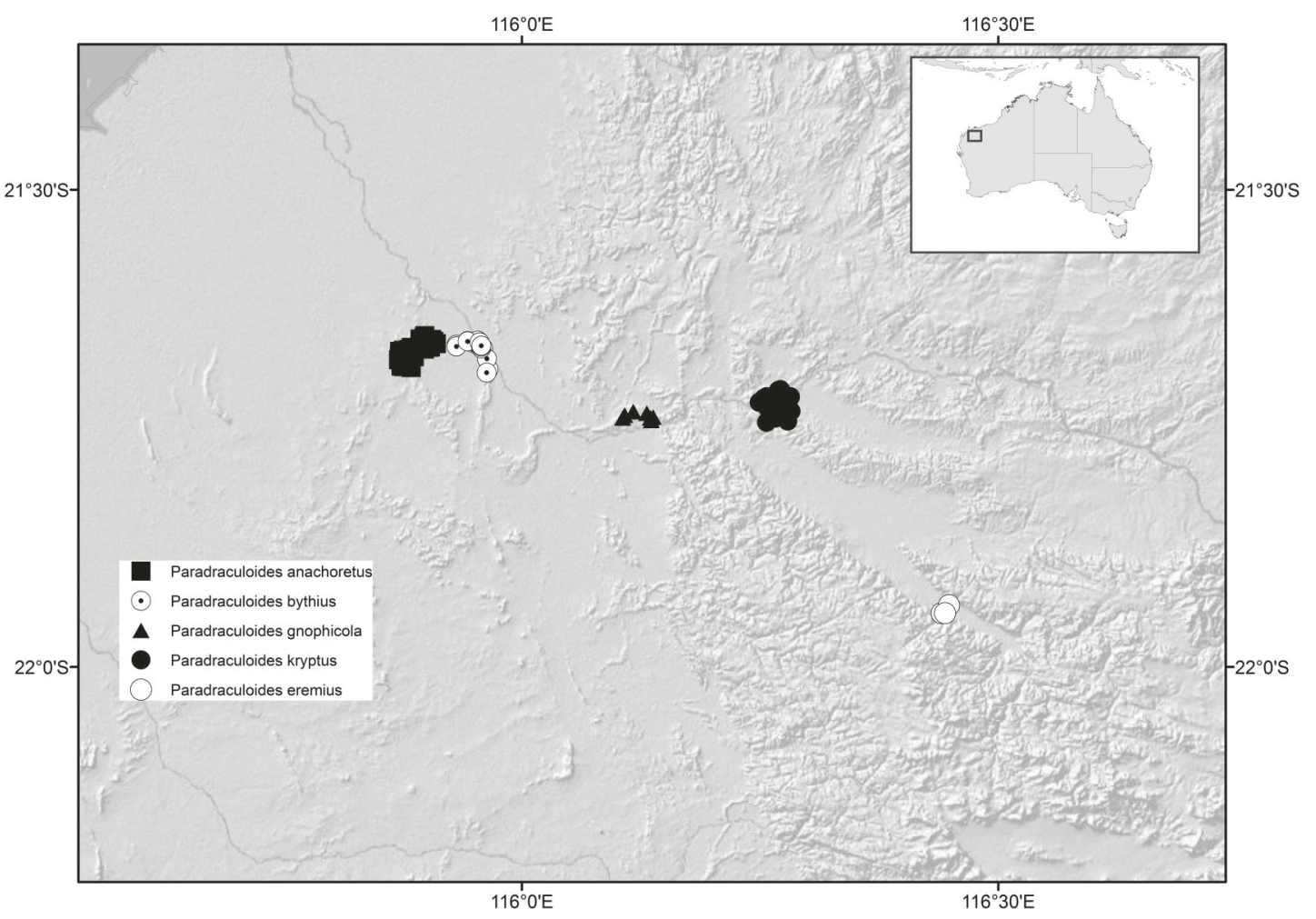

FIGURE 1 Known distribution of Paradraculoides eremius sp. nov., with the four other named species of the genus.

large and one small accessory teeth present near middle of file.

Pedipalp: without apophyses; trochanter with sharply produced distal extension, ventral margin with stout setae, without mesal spur; tibia and tarsus lacking spines; tarsus with spurs; claw $0.47\left({ }^{\Uparrow}\right), 0.42(+)$ length of tarsus.

Legs: tarsus I with six segments; femur IV $2.81($ ふ), $2.82(+9) \times$ longer than wide; anterodorsal margin of femur IV produced at about a $90^{\circ}$ angle.

Abdomen: chaetotaxy of tergites I-IX: $\widehat{0}$, two macrosetae + four microsetae (microsetae diagonal): three macrosetae + six microsetae (microsetae in column): 2: 2: 2: 2: 2: 2: 2 ; + , two macrosetae + four microsetae (microsetae diagonal): three macrosetae + six microsetae (microsetae in column): 3: 2: 2: 2: 2: 2 : 2 ; segment XII of male and female with small dorsal process.

Flagellum: male: broad, distally rounded posteriorly, $1.8 \times$ longer than broad (Figures 4-6); seta dm1 situated dorso-medially, seta dll small, situated posterior to vll, dm4 small, situated distally between dl3, dl3 situated at posterior margin, vm1 situated slightly posterior to vm2, vm4 situated between vm1 and vm5, vm5 slightly posterior to vl1, vl2 situated distally, additional microsetae present near d11, dl3 and vl2. Female: three segmented (Figures 7-9), first segment slightly longer than second, third longest, slightly curving upwards posteriorly, $4.88 \times$ longer than broad, one pair of microsetae positioned laterally on anterior end of second segment, two pairs additional microsetae present near v12 and d13, seta dm1 situated dorso-medially, seta d11 situated dorsolaterally between $\mathrm{dm} 1$ and $\mathrm{dm} 4, \mathrm{dm} 4$ situated subdistally, closer to dl3 than to dl1, dl3 situated at posterior margin slightly posterior to $\mathrm{vl} 2$, vml large, situated slightly anterior to vm2, vm4 situated midway between vm1 and vm5, vm5 situated slightly closer to $\mathrm{vm} 4$ than to vl2, vl1 posterior to $\mathrm{vm} 4$ and anterior to $\mathrm{dll}$.

Female genitalia: Two pairs of spermathecae, each pair connected basally before connection with bursa, distally round and smooth (Figure 10); evenly covered with small pores; gonopod rectangular and folded back like a tongue.

Dimensions (mm): Holotype $\widehat{\sigma}$ (paratype + , WAM T114972): Body length 4.30 (3.29). Propeltidium 1.15/0.64 (0.95/0.65). Chelicera $0.43(0.28)$. Flagellum 0.35/0.19 (0.39/0.08). Pedipalp: trochanter 0.51 (0.46), femur $0.52(0.55)$, patella $0.54(0.57)$, tibia $0.51(0.53)$, tarsus $0.28(0.25)$, claw $0.06(0.06)$, total excluding claw 2.36 (2.42). Leg I: trochanter $0.60(0.53)$, femur 0.43 (0.37), patella 1.57 (1.16), tibia 2.02 (1.37), metatarsus 1.43 (1.11), tarsus $1.23(0.92)$, total 7.28 (6.89). Leg IV: trochanter $0.40(0.32)$, femur 1.32/0.47 (1.07/0.38), patella 0.53 (0.42), tibia $1.02(0.78)$, metatarsus 0.89 (0.74), tarsus $0.60(0.55)$, total $4.76(3.88)$.

Variation: propeltidium length $0.95-1.15 \mathrm{~mm}(\mathrm{n}=3)$. 


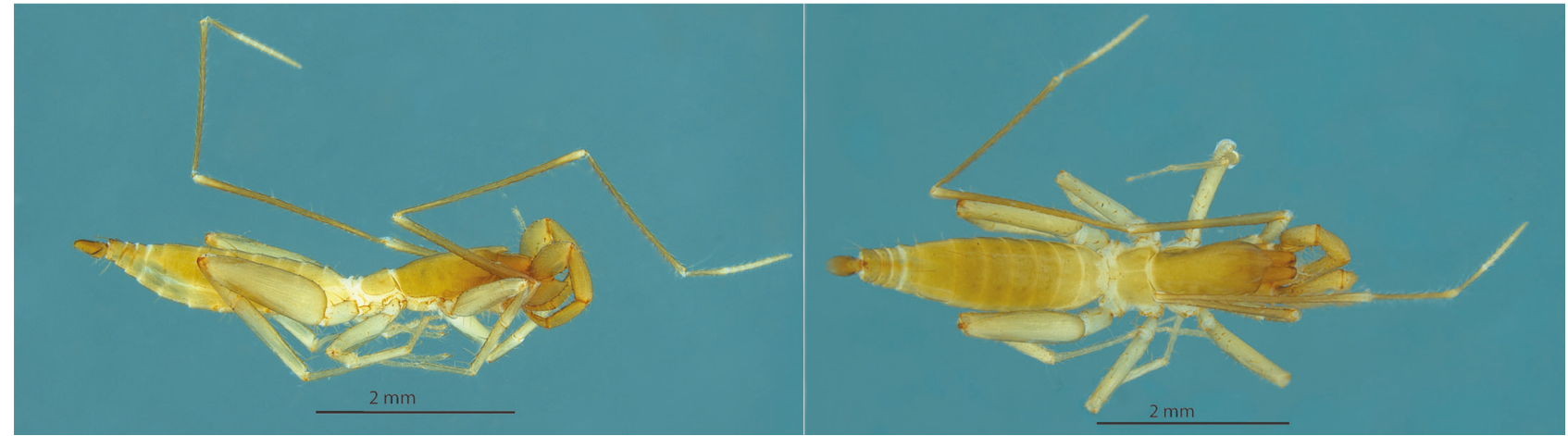

FIGURES 2-3 Paradraculoides eremius sp. nov., male holotype (WAM T114968), lateral and dorsal views, respectively. Scale bar $=2 \mathrm{~mm}$.
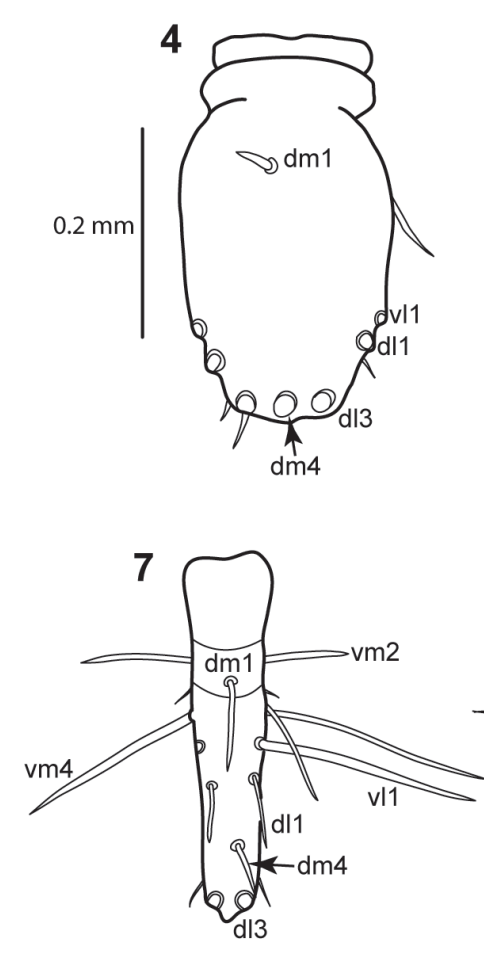
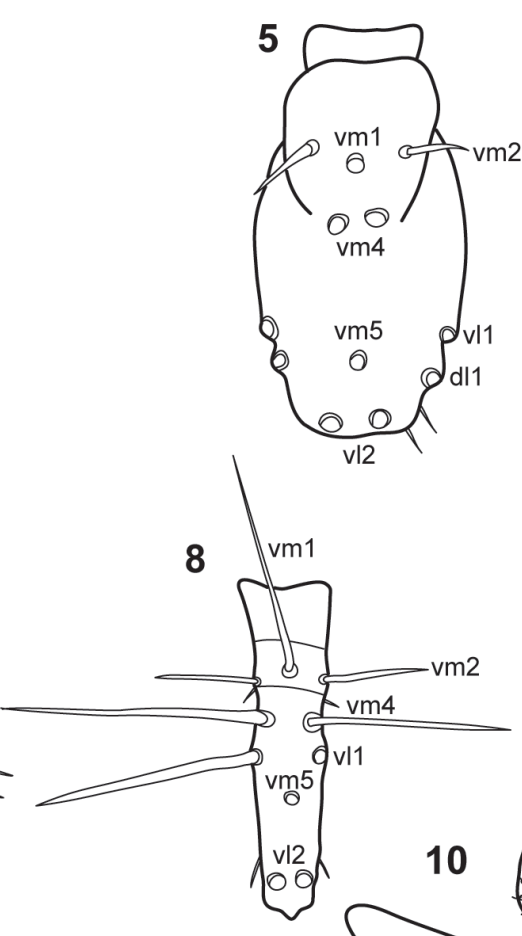

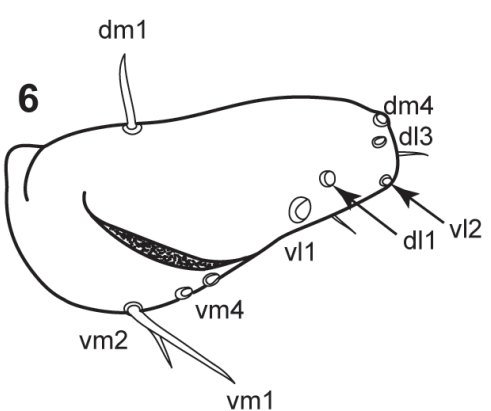

9

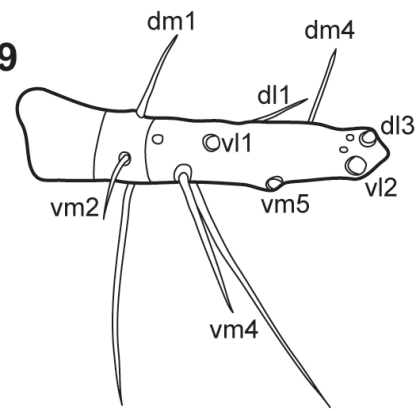

$\mathrm{vm} 1$

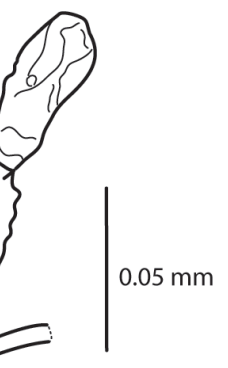

FIGURES 4-10 Paradraculoides eremius sp. nov.: 4-6, male holotype (WAM T114968): 4, flagellum, dorsal; 5, flagellum, ventral; 6, flagellum, lateral; 7-10, female paratype (WAM T114972): 7, flagellum, dorsal; 8, flagellum, ventral; 9 , flagellum, lateral; 10, genitalia, dorsal, damaged during collection. The scale bar beside figure 4 also applies to figures 5-9. See Materials and Methods for setal abbreviations. 


\section{REMARKS}

Paradraculoides eremius sp. nov. has only been found in channel iron deposits in the Bungaroo valley, situated south-east of Pannawonica in the Pilbara region of Western Australia.

\section{ETYMOLOGY}

The specific epithet refers to the solitary existence of this species within the subterranean environment in Bungaroo (eremius, Greek, solitude, desert, wilderness).

\section{ACKNOWLEDGEMENTS}

We are grateful to staff of Biota Environmental Sciences (Jason Alexander and Scott Werner) for collecting these specimens. Funds to support KMA were supplied by RioTinto and facilitated by Caitlin O’Neill and Sam Luccitti. We also thank Joel Huey and Mia Hillyer (Western Australian Museum, Perth) for supplying the CO1 sequence data. Sequencing was supported by a Gorgon Barrow Island Net Conservation Benefits grant administered by the Western Australian Department of Parks and Wildlife.

\section{REFERENCES}

Guzik, M.T., Austin, A.D., Cooper, S.J.B., Harvey, M.S., Humphreys, W.F., Bradford , T., Eberhard, S.M., King, R.A., Leys, R., Muirhead, K.A. and Tomlinson, M. (2011). Is the Australian subterranean fauna uniquely diverse? Invertebrate Systematics 24: 407-418.

Harvey, M.S. (1988). A new troglobitic schizomid from Cape Range, Western Australia (Chelicerata: Schizomida). Records of the Western Australian Museum 14: 15-20.

Harvey, M.S. (1992). The Schizomida (Chelicerata) of Australia. Invertebrate Taxonomy 6: 77-129.
Harvey, M.S. (2013). Schizomids of the world. http://www. museum.wa.gov.au/catalogues/schizomids (Western Australian Museum: Perth), Accessed on 18 August 2015.

Harvey, M.S. and Humphreys, W.F. (1995). Notes on the genus Draculoides Harvey (Schizomida: Hubbardiidae), with the description of a new troglobitic species. Records of the Western Australian Museum, Supplement 52: 183-189.

Harvey, M.S., Berry, O., Edward, K.L. and Humphreys, G. (2008). Molecular and morphological systematics of hypogean schizomids (Schizomida: Hubbardiidae) in semiarid Australia. Invertebrate Systematics 22: 167-194.

Humphreys, W.F. (1989). The biology of Schizomus vinei (Chelicerata: Schizomida) in the caves of Cape Range, Western Australia. Journal of Zoology, London 217: 177-201.

Humphreys, W.F. (2006). Aquifers: the ultimate groundwaterdependent ecosystems. Australian Journal of Botany 54: $115-132$.

Humphreys, W.F. (2008). Rising from Down Under: developments in subterranean biodiversity in Australia from a groundwater fauna perspective. Invertebrate Systematics 22: $85-101$

Humphreys, G., Alexander, J., Harvey, M.S. and Humphreys, W.F. (2013). The subterranean fauna of Barrow Island, north-western Australia: 10 years on. Records of the Western Australian Museum, Supplement 83: 145-158.

Ramanaidou, E.R., Morris, R.C. and Horwitz, R.C. (2003). Channel iron deposits of the Hamersley Province, Western Australia. Australian Journal of Earth Sciences 50: 669690

Reddell, J.R. and Cokendolpher, J.C. (1995). Catalogue, bibliography, and generic revision of the order Schizomida (Arachnida). Texas Memorial Museum, Speleological Monographs 4: 1-170.

Zawierucha, K., Szymkowiak, P., Dabert, M. and Harvey, M.S. (2013). First record of the schizomid Stenochrus portoricensis (Schizomida: Hubbardiidae) in Poland, with DNA barcode data. Turkish Journal of Zoology 37: 357-361.

MANUSCRIPT RECEIVED 24 AUGUST 2015; ACCEPTED 7 SEPTEMBER 2015. 